\title{
Kamışsı Yumak (Festuca arundinaceae), Çayır Salkım Otu (Poa pratensis), Kırmızı Yumak (Festuca rubra) ve İngiliz Çimi (Lolium perenne) Çeşitlerinin Çim Alan Özellikleri
}

\author{
*Hüseyin VAROĞLU1 \\ Rıza AVCIOĞLU² \\ Reşat DEĞíRMENCi ${ }^{1}$ \\ ${ }^{1}$ K.K.T.C. Tarım ve Doğal Kaynaklar Bakanlığı, Tarımsal Araştırma Enstitüsü, Kıbrıs \\ ${ }^{2}$ Ege Üniversitesi, Ziraat Fakültesi Tarla Bitkileri Anabilim Bölümü İzmir, Türkiye \\ *Sorumlu yazar e-posta (Corresponding author; e-mail): huseyinvaroglu@hotmail.com
}

Geliş Tarihi (Received): 27.08.2015

Kabul Tarihi (Accepted): 02.12.2015

\section{Öz}

Bu çalışma, 2007-2008 yılları arasında, Ege Üniversitesi Ziraat Fakültesi, Tarla Bitkileri Bölümü'nün Bornova deneme tarlalarında, dünyada yaygın olarak kullanılan 3 değişik cinse (Lolium sp., Poa sp., Festuca sp.) dahil toplam 12 farklı serin iklim (C3) çim buğdaygilinin, Akdeniz iklim koşullarına adaptasyonunu ve çim performanslarını ortaya koymak amacıyla yürütülmüştür. Araştırmada; Lolium perenne (Numan, Ovation, Delaware) Festuca rubra (Engina, Franklin, Pernille), Festuca arundunaceae (Eldorado, Finelawn, Apache), Poa pratensis (Enprima, Geronimo, Connni) çeşitlerinin çim alan özellikleri incelenmiştir. Bu amaçla Çıkış Hızı (Gün), Kaplama Hızı (Gün), Kışa Dayanıklııı (1-9), Kaplama Derecesi (\%), Yaprak Dokusu (1-9), Yaprak Rengi (1-9), Yenilenme Gücü (1-5), ) Kardeş Sayısı (1-5), Genel Görünüm (1-9), Yabancı Ot Oranı (1-5) ve Seyrekleşme Derecesi karakterleri ele alınmıştır. Elde edilen bulgulara göre; Festuca arundinaceae'nin yeni çeşitleri pek çok özellik (Kaplama Derecesi, Yaprak Dokusu, Yaprak Rengi, Yenilenme Gücü) açısından en iyi sonucu vermiştir. Aynı zamanda Lolium perenne'nin yeni çeşitleri de başarılı olmuştur. Poa pratensis ve Festuca rubra yeni çeşitleri ise birçok özellik açısından başarılı olamamıştır.

Anahtar Kelimeler: Festuca arundinaceae, Poa pratensis, Festuca rubra, Lolium perenne, çim kalitesi

\section{Turf Characteristic of Tall Fescue (Festuca arundinaceae) Bluegrass (Poa pratensis), Red Fescue (Festuca rubra) and the British Grass (Lolium perenne)}

\begin{abstract}
This study was conducted in order to determine the adaptability and performances of 12 different species of 3 various world widely used C3 cool-season turf grass genera (Lollium sp., Poa sp., Festuca sp.), on the experimental fields of Faculty of Agriculture, Ege University under Mediterranean ecological conditions of Izmir in 2007-2008. Turf properties of different cultivators of Lolium perenne (Numan, Ovation, Delaware) Festuca rubra (Engina, Franklin, Pernille), Festuca arundunaceae (Eldorado, Finelawn, Apache) and Poa pratensis (Enprima, Geronimo, Connni) were tested in the experiment. For this aim, characters such as gemination rates (day), crop cover (day), cold resistance (1-9 point), cover rate (\%), texture (1-9 point), color (1-9 point), recover (1-5 point), tillering (1-5 point), General Outlook (1-9 point), weed investigation (1-5 point) and rate of thinning were determined. Results According to the findings that Festuca arundunaceae cultivars were the most proper material and Lolium perenne cultivars were also successful. Both Festuca rubra and, Poa pratensis cultivars failed in terms of many properties.
\end{abstract}

Keywords: Festuca arundinaceae, Poa pratensis, Festuca rubra, Lolium perenne, turf quality

\section{Giriş}

$\mathrm{D}$ ünyada hızlı nüfus artışı nedeniyle şehirlerin hızla gelişmesi ve yoğun yapılaşma, şehirlerde yeşil alanların ve özellikle yüzey etkisi oluşturan çim alanların önemini daha da artırmıştır. Özellikle yapı teknolojisindeki gelişmeler sonucu, yoğun ve büyük binalar arasındaki boşlukların çim alan olarak düzenlenmesi önem kazanmıştır. Yine, büyük şehirlerdeki apartmanların arasında, küçük yerleşim yerlerinde ve Kıbrıs'ta da sahil boyunca yapılan yazlık evlerin, villaların bahçelerinin düzenlenmesi için çim bitkilerinden faydalanılmaktadır. 
Yeşil alanların içinde en küçük birim olan ev bahçelerinden sitelerdeki geniş bahçelere ve büyükşehir parklarına kadar ağaç, çalı ve yer örtücü bitkileri görebiliriz. Yeşil alanlardaki yer örtücü bitkiler arasında en büyük payı çimler almaktadır. Bu alanların bilinçli bir şekilde kullanımları için, çim buğdaygillerinin orijinlerini, formlarını, özelliklerini, yetişme şekillerini, yetişme ortamlarını, hastalık ve zararlılarla savaşım tekniklerini ve uygun mekanizasyon işlemlerini detaylı olarak bilmeye gerek vardır (Uçucu 1993). Fakat bu alanlarda, bilinçsiz ve yanlış bakım uygulamaları sonucu; örneğin, intiyaçtan daha fazla sıklıkta ve miktarda gübre uygulaması nedeniyle ekonomik yönden kayıplar oluşmakta ve çevre kirliliği ortaya çıkmaktadır. Yine Kıbrıs'ta, aşırı gübreleme ile birlikte yapılan aşırı sulama ile çim alanlar bozulmakta ve keçeleşme görülmekte, görüntü kirliliği giderek artmaktadır. Diğer önemli bir sorun da kullanılacak olan çim bitkilerinin seçimidir. Yeşil alanlarda kullanılacak çimler, ekolojik koşullara ve tesis amaçlarına göre, bir kaç farklı cinsten oluşmakta, iyi bir yeşil alan için en uygun tür, cins ve çeşidin seçimi çok büyük önem taşımaktadır.

Ege Bölgesi Akdeniz iklim kuşağında, yeşil alan oluşturmak için genellikle İngiliz çimi (Lolium perenne), çayır salkımotu (Poa pratensis) kırmızı yumak (Festuca rubra) ve kamışı yumak (Festuca arundinaceae) gibi serin iklim çim türleri kullanılmaktadır. Genellikle kısa sürede çimlenip yeşil örtü oluşturması ve tohumunun ucuz olması nedenleri ile hemen hemen her yeşil alan uygulamasında İngiliz çimi (Lolium perenne) vazgeçilmez bir bitki özelliği taşımaktadır. Kıbrıs koşullarında genellikle yazın yapılan düzenlemelerde, yukarıdaki serin iklim çim bitkilerinin yerine Bermuda Çimi (Cynodon dactylon), Zenci darısı çimi (Pennisetum clandestinum) ve yengeç çimi (Stenotaphrum secundatum) çeşitleri kullanılmaktadır. Ülkede, İngiliz çimi ise, sonbaharda bermuda çimi üzerine üsten tohumlama yapılarak ekilmektedir. Son yıllarda sıcağa dayanıklı Festuca arundinaceae'nin kullanımı da artmaktadır.

Araştırmamızı yürüttüğümüz ve Akdeniz iklim koşulları altındaki Ege bölgesinde 4'lü veya 5'li karışım adı altında Lolium, Festuca ve Poa cinsine ait çok sayıda çeşitlerden oluşturulan karışımlar kullanılmakta, özellikle cins tür ve çeşit seçiminde yapılan hatalar nedeni ile de pek çok olumsuzlukla karşılaşılmaktadır. Bölgenin sıcak iklim koşullarında anılan serin iklim çimlerini yetiştirmenin güçlükleri ortadadır. Ancak hiç olmazsa bölgeye adapte olabilecek çeşitleri seçerek daha başarılı karışımlar ve yeşil alan örtüleri oluşturmak mümkündür. Son yıllarda özellikle Lolium ve Festuca cinsine ait tür ve çeşitlerde sıcak ve kurağa dayanıklıık açısından yoğun ıslah çalışmaları yapılmaktadır. Islah çalışmaları sonucunda tescil edilen yeni çeşitlerde, özellikle sıcağa dayanıklılığın önemli düzeyde artııılığı da bilinmektedir (Avcıoğlu 1997).

Araştırmamızda, bazı yeni Festuca arundinaceae, Poa pratensis, Lolium perenne ve Festuca rubra çeşitlerinin, bölgede uzun yıllar kullanılan eski çeşitlerle karşılaştırılması ve bölge için uygun olacağı düşünülen yeni çim bitkilerinin belirlenmesi amaçlanmıştır.

\section{Materyal ve Yöntem}

Araştırma, 2007-2008 yetiştirme döneminde; Ege Üniversitesi Ziraat Fakültesi (EÜZF) Tarla Bitkileri Bölümü İzmir Bornova deneme tarlalarında gerçekleştirilmiştir. Denemenin yürütüldüğü yıllara ve uzun yıllara ait iklim verileri Çizelge 1'de verilmiştir. Çizelgeden görüldüğü gibi, araştırmanın yapıldığı yıldaki sıcaklık ortalamaları uzun yıllar sıcaklık ortalamalarından yüksek olmuştur. Deneme yerinin iklimsel özeliklerine göre, denemede kullanılan bitkisel materyallerin büyüme ve gelişmesini engelleyen bir unsur bulunmamaktadır.

Deneme alanı toprağı $0-20 \mathrm{~cm}$ derinlikte millikilli, $20-40 \mathrm{~cm}$ derinlikte ise killi-tınlı özellikler taşımaktadır. Bornova ovasını temsil eden bu alüviyal toprak yapısı, oldukça ağır toprak niteliğini ifade etmektedir. Deneme alanının 0-20 $\mathrm{cm}$ derinliğinde tespit edilen 8.2'lik pH değeri, deneme yeri toprağının yüzeyde orta alkali; 20 $40 \mathrm{~cm}$ derinlikteki $7.8^{\prime}$ lik pH değeri ise hafif alkali tepkimeli olduğunu göstermektedir. Deneme alanının her iki katmanındaki topraklarda tespit edilen kireç yüzdeleri, toprağın kireççe zengin olduğunu ortaya koymaktadır. Elektriksel konduktivite cihazı ile yapılan analiz sonucunda, suda eriyebilir tuz değerleri (\%0.095-0.075) bitki yetiştirme açısından herhangi bir sorun olmadığını göstermektedir. Her iki toprak derinliğinde tespit edilen organik ve inorganik madde bulguları, bu toprakların organik maddece fakir, toplam azotça orta düzeyde, faydalı fosforca fakir ve faydalı potasyumca zengin olduğunu ortaya koymaktadır (Kacar 1986 ve Kovancı 1990).

Yapılan araştırmada Ege Bölgesi'nde özel sektörce pazara sunulan ve çim alan düzenlemelerinde çok yaygın olarak kullanılan cins, tür ve çeşitler ile bölgeye uygunluklarını 
Varoğlu et al. "Turf Characteristic of Tall Fescue (Festuca arundinaceae) Bluegrass (Poa pratensis), Red Fescue (Festuca rubra) and the British Grass (Lolium perenne)"

Çizelge 1. Araştırma yerine ait iklim verileri

Table 1. Climate data belong to research area

\begin{tabular}{lcccccc}
\hline & \multicolumn{2}{c}{$\begin{array}{c}\text { Ortalama Sıcaklık } \\
\left({ }^{\circ} \mathrm{C}\right)\end{array}$} & \multicolumn{2}{c}{$\begin{array}{c}\text { Toplam YağıŞ } \\
(\mathrm{mm})\end{array}$} & \multicolumn{2}{c}{$\begin{array}{c}\text { Oransal Nem } \\
(\%)\end{array}$} \\
\hline Aylar & $2007-2008$ & Son 10 Yıllık & $2007-2008$ & Son 10 Yılık & $2007-2008$ & Son 10 Yıllık \\
\hline Ocak & 10,6 & 8,4 & 33,1 & 96,2 & 62,2 & 64,1 \\
Şubat & 10,6 & 8,7 & 22,6 & 92,7 & 66,9 & 63,2 \\
Mart & 13,4 & 11,4 & 29,7 & 69,2 & 59,8 & 59,2 \\
Nisan & 16,2 & 15,4 & 19,3 & 45,9 & 48,8 & 58,5 \\
Mayıs & 22,4 & 21 & 44,1 & 29,3 & 52,2 & 53,3 \\
Haziran & 27,5 & 26,3 & 0,3 & 6,2 & 44,7 & 45,8 \\
Temmuz & 30,1 & 29,1 & 0 & 1,7 & 38,7 & 44,2 \\
Ağustos & 29,2 & 28,3 & 0 & 1,8 & 45,8 & 47,9 \\
Eylül & 24,4 & 23,2 & 0 & 29,7 & 48,8 & 53,7 \\
Ekim & 19,7 & 18,6 & 107,7 & 54 & 64,5 & 59,4 \\
Kasım & 13,9 & 13,4 & 111,6 & 111,7 & 69,3 & 66,3 \\
Aralık & 9 & 9,7 & 118,8 & 96,6 & 70 & 64,9 \\
\hline X/ $\Sigma$ & 18,9 & 17,8 & 40,6 & 52,9 & 56,0 & 56,7 \\
\hline
\end{tabular}

Çizelge 2. Araştırmada kullanılan bitki materyali

Table 2. Used in research plant materials

\begin{tabular}{llllll}
\hline Bilimsel Adı & Türkçe Adı & Çeşit Adı & Bilimsel Adı & Türkçe Adı & Çeşit Adı \\
\hline Festuca arundinacea & Kamışsı yumak & Eldorado & Lolium perenne & İngiliz çimi & Numan \\
Festuca arundinacea & Kamışı yumak & Finelawn & Lolium perenne & İngiliz çimi & Ovation \\
Festuca arundinacea & Kamışsı yumak & Apache & Lolium perenne & İngiliz çimi & Delaware \\
Festuca rubra & Kırmızı yumak & Engina & Poa pratensis & Çayır salkım otu & Enprima \\
Festuca rubra & Kırmızı yumak & Franklin & Poa pratensis & Çayır salkım otu & Geronimo \\
Festuca rubra & Kırmızı yumak & Pernille & Poa pratensis & Çayır salkım otu & Conni \\
\hline
\end{tabular}

incelemek amacıyla seçilen yeni çeşitlerin Türkçe ve bilimsel isimleri Çizelge 2'de açıklanmıştır.

Araştırmada bir vejetasyon süresi içinde aşağıdaki özellikler gözlenip ölçülmüştür. (Anonim, 2001).

Denemede ele alınan gözlem ve
ölçümler;

a) Çıkış Hızı (Gün): Ekim tarihi ile parselde $\% 50$ çıkışın tespit edildiği tarih arasındaki gün sayılmıştır.

b) Kaplama Hızı (Gün): Ekim tarihi ile parselin \%75'inin tamamen bitki ile kaplandığı tarih arasındaki gün sayılmıştır.

c) Kışa Dayanıklılık (1-9): Gözlemler; Şubat ayı sonunda, ilkbahar büyüme başlangıcından önce yapılmıştır. 1= Çok Kötü ( Bitkilerin Tümü Ölü), 3= Kötü (Bitkilerin \%50'si ölü), 5= Orta (Parselin Tümü Sararmış), 7= İyi ( Parselin \%50'den azı Sararmış), 9= Çok İyi (Parselde Herhangi Bir Sararma Yok).

d) Kaplama Derecesi (\%): İlkbahar gelişme döneminde 2'inci biçimden sonra, parselin bitki ile kaplı olduğu alan tespit edilmiş ve aşağıdaki gibi sınıflandırılmıştır. 1= Çok Seyrek (\%20), 3= Seyrek (\%20-40), 5= Orta (\%40-60), 7=Sık $(\% 60-80), 9=$ Çok Sık $(\% 80-100)$. e) Yaprak Dokusu (1-9): Yaprak dokusunun genişliği; çeşidi temsil edecek boyuttaki yapraklarda ve yaprağın en geniş yerinde cetvel ile ölçülüp tespit edilmiştir. 1= Çok Kaba (4 mm'den fazla), 3= Kaba (3-4 mm), 5= Orta (2-3 mm), 7= İnce (1-2 mm), 9= Çok ince (1 mm' den daha az).

f) Yaprak Rengi (1-9): Gözlemler; İlkbahar, Yaz, Sonbahar ve Kış mevsimlerinde ve her mevsimin karakteristik yaprak rengini temsil eden ayların orta döneminde yapılmıştır. 1= Sarı, 3= Açık Sarı-Yeşil, 5= Yeşil, 7= Koyu Yeşil, 9= Çok Koyu Yeşil.

g) Yenilenme Gücü (1-5): İlkbahar döneminde ve 2. Biçimden önce türler kendi aralarında 1-5 skalasına göre değerlendirilmiştir. 1= Çok Hızıı Büyüme, 3= Orta Büyüme, 5= Çok Yavaş Büyüme.

h) Kardeş Sayısı (1-5): İlkbaharda 2. Biçimden hemen sonra kardeşlerin bitki dokusu içerisindeki sıklık durumu incelenmiş ve 1-5 skalasına göre değerlendirilmiştir. 1= Çok Seyrek, 3=Orta, 5= Çok Sık.

i) Genel Görünüm (1-9): Parseller; her mevsim genel çim özelliği, üniformite, renk, doku, canlılık yabancı ot, hastalık ve zararlılar bakımından gözlenerek ve 1-9 skalasına göre değerlendirilmiştir. 1= Çok Kötü, 3= Kötü , 5= Orta, $7=$ İyi, 9= Çok İyi. 
j) Yabancı Ot Oranı (1-5): Vejetasyon dönemi sonunda yapılan son biçimden sonra parseldeki yabancı bitki oranları gözlenmiş ve 1-5 skalasına göre değerlendirme yapılmıştır. $1=$ Çok, 3= Orta, 5= Yabancı Bitki Yok.

k) Seyrekleşme Derecesi (1-9): Vejetasyon dönemi sonunda parselin çim örtüsünde seyrekleşme derecesi gözlenmiş, 1-9 skalasına göre değerlendirme yapılmıştır. $1=$ Çok Seyrek, $3=$ Seyrek, $5=$ Orta, $7=$ Sık, $9=$ Çok Sık.

Araştırmadan elde edilen veriler, EÜZF Tarla Bitkileri Bölümü, Çayır-Mer'a ve Yem Bitkileri Bilim Dalı Bilgisayar Laboratuvarında hazır paket program TOTEMSTAT yardımıyla varyans analizine tabi tutulmuş ve ortalamaların karşılaştııılmasında LSD testi kullanılarak \%5 önem seviyesine göre gruplandırılmıştır.

\section{Bulgular ve Tartışma}

Çıkış Hızı: Çizelge 3 incelendiğinde; kamışsı yumak çeşitlerinin çıkış hızı özellikleri açısından 8,2 gün ortalama ile çeşitler arasında önemli bir fark olmadığı anlaşıımaktadır. Buna karşılık çayır salkımotu çeşitleri çok daha geç sürede ve ortalama 17.7 günde çıkış sağlayabilmiş, bu çeşitlerden Geronimo 20.8 gün ile denemede en geç çıkış sağlayan çeşit olmuştur. Çıkış hızı açısından İngiliz çimi çeşitleri ortalama 4.8 gün ile en hızlı çıkışı gerçekleştirmişlerdir. Kırmızı yumak çeşitleri arasında çıkış hızı açısından önemli bir fark oluşmamış ve ortalama 6.9 günde tüm çeşitler çıkışlarını tamamlamıştır. Çıkış hızına ilişkin bulgularımız, ele alınan çim çeşitlerinde tohum boyutları küçüldükçe çıkış hızının azaldığını ve çeşitlerin daha uzun sürede çıkış sağlayabildiğini göstermektedir.

Kaplama Hızı: Çizelge 3'de görüldüğü gibi, deneme bitkileri kaplama hızı özellikleri açısından irdelendiğinde, İngiliz çimi çeşitlerinin ortalama 28.3 gün ile diğer çeşitlere nazaran, alanı en hızlı sürede kapladıkları anlaşılmaktadır. İngiliz çimi çeşitleri arasında ise 27.0 gün ile Ovation'ın en hızlı sürede kaplama sağladığı izlenmektedir. Buna karşılık, çayır salkımotu çeşitleri ortalama 57.8 gün ve bunların arasında yer alan Enprima 60.0 gün ile alanı en uzun sürede kaplamışlardır. Kırmızı yumak çeşitleri, kaplama hızı açısından ortalama 31.0 gün ile ve kamışsı yumak çeşitleri de ortalama 48.7 gün ile İngiliz çimi ve çayır salkımotu çeşitlerinin arasında yer almışlardır. Kaplama hızına ilişkin bulgularımıza göre, ele alınan çim çeşitleri arasında önemli farklılıkların oluştuğu gözlenmektedir. Özellikle küçük tohumlu çeşitler (çayır salkımotu) geç kaplama sağlarken (ortalama 57.8 gün) ona nazaran iri tohumlu çeşitlerin (kamışsı yumak, kırmızı yumak ve İngiliz çimi), alanı daha erken sürede (sırasıyla 48.7, 31.0, 28.3 gün) kapladıkları izlenmektedir. Bu sonuçta, çıkış hızlarının da etkili olduğu kuşkusuzdur.

Kışa Dayanıklılık: Çizelge 3'de özetlenen kışa dayanıklılık özellikleri incelendiğinde uygulanan istatistik analiz sonuçları, denemede kullanılan çim türleri arasında önemli farklılıklar olduğunu göstermektedir. Buna göre, en yüksek kışa dayanıklıık değeri (9.0) İngiliz çimi ve Kamışsı yumak çeşitlerinde görülmektedir. En düşük değeri (8.7) ise Kırmızı yumak çeşitleri almıştır. Çayır salkımotu da 8.8'lik değerle kışa oldukça dayanıklı bir özellik sergilemiştir. Kışa dayanıklılığa ilişkin özellikler türler arasında bazı farklılıkların oluştuğunu ortaya koymuştur. Kışa dayanıklılık bakımından, İngiliz çimi ve Kamışsı yumak çeşitleri İzmir'in Akdeniz iklim kuşağında olması ve havaların çok fazla soğumaması nedeniyle iyi bir dayanıklılık göstererek kışı başarılı şekilde atlatmışlardır. Avcıoğlu (1997), İngiliz çimi ve kamışı yumağın kışı sert olmayan bölgelere çok iyi adapte olduklarını açıklamaktadır. Buna karşılık Demiroğlu ve Soya (2000), çayır salkımotu, İngiliz çimi ve kırmızı yumağın kışa dayanıklı çeşitler olduklarını açıklamaktadırlar. Ancak, bizim çalışmamızda ve İzmir'in Akdeniz iklim koşullarında bu çim türleri (çayır salkımotu ve kırmızı yumak) yaz sıcaklarından çok zarar görmüşler ve kışa yıpranmış olarak girdiklerinden, sonuçlarımız Demiroğlu ve Soya (2000)'nın sonuçlarını doğrulamamıştır. Araştırmamızın bu bölümünde, İngiliz çiminde kış sararması ve ölümleri diğer çimlere nazaran çok daha az görülmüştür. $\mathrm{Bu}$ sonuçlarımız birçok araştırıcının verileri ile de uyumlu bulunmuştur (Arslan ve Çakmakçı 2004; Cockerham ve ark. 1989). Çalışmamızda ele aldığımız tüm cins, tür ve çeşitler serin iklim bitkisi olduğundan ve ayrıca deneme yerindeki kış koşulları da ılıman Akdeniz iklim özellikleri taşıdığından, tüm tür ve çeşitler kışa dayanıklıık açısından başarılı sonuçlar vermiştir. 
Varoğlu et al. "Turf Characteristic of Tall Fescue (Festuca arundinaceae) Bluegrass (Poa pratensis), Red Fescue (Festuca rubra) and the British Grass (Lolium perenne)"

Çizelge 3. Kamışsı yumak (Festuca arundinaceae), kırmızı yumak (Festuca rubra), İngiliz çimi (Lolium perenne) ve çayır salkımotu (Poa pratensis) çeşitlerinin çıkış hızları (gün) kaplama hızları (gün) ve kışa dayanıklılık değerleri (1-9 puan)

Table 3. Output speed (day), finish rates (day) and winter endurance (1-9 points) of tall fescue (Festuca arundinacea), red fescue (Festuca rubra), the British grass (Lolium perenne) and bluegrass (Poa pratensis) types

\begin{tabular}{llccc}
\hline Çim Buğdaygilleri & Çeşitler & Çıkış Hızı & Kaplama Hızı & Kışa Dayanıklılık \\
\hline \multirow{2}{*}{ Kamışsı Yumak } & Eldorado & $8.3 \mathrm{c}$ & $48.8 \mathrm{e}$ & $9.0 \mathrm{a}$ \\
(Festuca arundinaceae) & Finelawn & $8.3 \mathrm{c}$ & $48.3 \mathrm{e}$ & $9.0 \mathrm{a}$ \\
Ortalama & Apache & $8.0 \mathrm{c}$ & $49.0 \mathrm{e}$ & $9.0 \mathrm{a}$ \\
\hline \multirow{2}{*}{ Kırmızı Yumak } & & 8.2 & 48.7 & 9.0 \\
(Festuca rubra) & Engina & $6.8 \mathrm{~b}$ & $29.5 \mathrm{cb}$ & $9.0 \mathrm{a}$ \\
Ortalama & Franklin & $6.8 \mathrm{~b}$ & $30.8 \mathrm{c}$ & $8.8 \mathrm{ab}$ \\
\hline \multirow{2}{*}{ Ingiliz Çimi } & Pernille & $7.0 \mathrm{~b}$ & $32.5 \mathrm{~d}$ & $8.3 \mathrm{c}$ \\
(Lolium perenne) & & 6.9 & 31.0 & 8.7 \\
Ortalama & Numan & $4.8 \mathrm{a}$ & $28.5 \mathrm{~b}$ & $9.0 \mathrm{a}$ \\
\hline \multirow{2}{*}{ Çayır Salkımotu } & Ovation & $4.8 \mathrm{a}$ & $27.0 \mathrm{a}$ & $9.0 \mathrm{a}$ \\
(Poa pratensis) & Delaware & $4.8 \mathrm{a}$ & $29.5 \mathrm{cb}$ & $9.0 \mathrm{a}$ \\
Ortalama & & 4.8 & 28.3 & 9.0 \\
\hline Genel Ortalama & Enprima & $16.0 \mathrm{~d}$ & $60.0 \mathrm{~g}$ & $8.5 \mathrm{bc}$ \\
LSD (\%5) & Geronimo & $20.8 \mathrm{e}$ & $56.0 \mathrm{f}$ & $8.8 \mathrm{bc}$ \\
\hline
\end{tabular}

Kaplama derecesi: Çizelge 4'de belirtilen kaplama derecesi özellikleri incelendiğinde, kamışsı yumak çeşitlerinin ortalama 8.8'lik puan ile en yüksek değerleri almış oldukları görülmektedir. Buna karşılık, çayır salkımotu çeşitleri ortalama 3.9 puan ile en düşük değeri almışlardır. İngiliz çimi çeşitleri ortalama 7.9 kırmızı yumak çeşitleri de ortalama 6.7 puan ile değerlendirilmiş ve kamışsı yumak ile çayır salkımotu çeşitleri arasındaki konumda yer almışlardır. Bu bölümde saptanan ve kırmızı yumağın en düşük kaplama derecesi oluşturduğunu gösteren veriler beklenene uymaktadır. Zira, çok soğuk koşullara adapte olan kırmızı yumak araştırma yerinin Akdeniz iklim koşullarında yaz sıcaklarından büyük zarar görmekte ve parseldeki bitkilerin büyük bölümü kaybedilmektedir. Avcıoğlu (1997)'da benzer sorunlara değinerek sonuçlarımızı doğrulamaktadır. Kırmızı yumak çeşitlerinin Akdeniz iklim koşullarındaki karışımlarda alt çim olarak yetiştirilebileceğini belirten Orçun (1979)'un görüşleri, bizim sonuçlarımızla uyumlu bulunmamakta, ancak bu çim türünün Akdeniz iklim koşullarından olumsuz etkilendiğini öne süren Avcıoğlu (1997)'nun sonuçlarıyla uyumlu bulunmaktadır. Kaplama derecesi açısından İngiliz çimi çeşitleri de başarılı olmuş ve özellikle Numan çeşidinin, bölgeye iyi adapte olması nedeniyle çok iyi bir kaplama derecesi sağladığı belirtilmiştir. Çayır salkımotu çeşitleri arasında ve tüm deneme kapsamında yer alan çeşitler arasında Geronimo en düşük puanı alarak (3.0), denememizde kaplama derecesi bakımından en zayıf çeşit olarak belirlenmiştir. Sonuç olarak, çayır salkımotu ve kırmızı yumak çeşitleri yazın büyük oranda kayıp vermiş ve zayıf bir çim örtüsü bırakmışlardır. Bu sonuçları Avcıoğlu (1992) ve Açıkgöz (1994)'ün sonuçları da doğrulamıştır. Bulgularımızda en iyi kaplama derecesini, kamışsı yumağın tüm çeşitleri ve İngiliz çiminin Numan çeşidi ortaya koymuştur. Ancak Yazgan ve ark. (1992) bulgularımızın aksine İngiliz çiminin Ovation çeşidini Bursa koşullarında en iyi kaplama derecesini sağlayan çeşit olarak bulmuşlardır. 
Varoğlu ve ark. "Kamışsı Yumak (Festuca arundinaceae), Çayır Salkım Otu (Poa pratensis), Kırmızı Yumak (Festuca rubra) ve Ingiliz Çimi (Lolium perenne) Çeşitlerinin Çim Alan Özellikleri"

Çizelge 4. Kamışsı yumak (Festuca arundinaceae), kırmızı yumak (Festuca rubra), İngiliz çimi (Lolium perenne) ve çayır salkımotu (Poa pratensis) çeşitlerinin kaplama derecesi (1-9 puan), yaprak dokusu (mm) ve yenilenme gücü (1-5 puan)

Table 4. Coating Degree (1-9 points), leaf tissue $(\mathrm{mm})$ and regeneration power (1-5 points) of tall fescue (Festuca arundinacea), red fescue (Festuca rubra), the British grass (Lolium perenne) and bluegrass (Poa pratensis) types

\begin{tabular}{llccc}
\hline \multirow{2}{*}{ Çim Buğdaygilleri } & Çeşitler & Kaplama Derecesi & Yaprak Dokusu & Yenilenme Gücü \\
\hline Kamışsı Yumak & Eldorado & $9.0 \mathrm{a}$ & $3.1 \mathrm{~b}$ & $2.0 \mathrm{a}$ \\
(Festuca arundinaceae) & Finelawn & $8.5 \mathrm{a}$ & $3.8 \mathrm{a}$ & $2.0 \mathrm{a}$ \\
& Apache & $8.8 \mathrm{a}$ & $3.8 \mathrm{a}$ & $2.0 \mathrm{a}$ \\
Ortalama & & 8.8 & 3.6 & 4.0 \\
\hline \multirow{2}{*}{ Kırmızı Yumak } & Engina & $2.7 \mathrm{e}$ & $1.3 \mathrm{~g}$ & $4.0 \mathrm{c}$ \\
(Festuca rubra) & Franklin & $2.8 \mathrm{e}$ & $1.3 \mathrm{~g}$ & $4.0 \mathrm{c}$ \\
& Pernille & $2.0 \mathrm{f}$ & $1.2 \mathrm{~g}$ & $4.0 \mathrm{c}$ \\
Ortalama & & 2.5 & 1.3 & 3.0 \\
\hline \multirow{2}{*}{ Ingiliz Çimi } & Numan & $8.5 \mathrm{a}$ & $2.0 \mathrm{de}$ & $3.0 \mathrm{~b}$ \\
(Lolium perenne) & Ovation & $7.5 \mathrm{~b}$ & $2.1 \mathrm{~cd}$ & $3.0 \mathrm{~b}$ \\
& Delaware & $7.8 \mathrm{~b}$ & $2.1 \mathrm{c}$ & $3.0 \mathrm{~b}$ \\
Ortalama & & 7.9 & 2.1 & 2.0 \\
\hline \multirow{2}{*}{ Çayır Salkımotu } & Enprima & $4.0 \mathrm{~d}$ & $1.6 \mathrm{f}$ & $5.0 \mathrm{e}$ \\
(Poa pratensis) & Geronimo & $3.0 \mathrm{e}$ & $1.9 \mathrm{e}$ & $5.0 \mathrm{e}$ \\
Ortalama & Conni & $4.8 \mathrm{c}$ & $1.6 \mathrm{f}$ & $5.0 \mathrm{e}$ \\
\hline Genel Ortalama & ----- & 3.9 & 1.7 & 5.0 \\
LSD (\%5) & ----- & 5.8 & 2.2 & 3.5 \\
\hline
\end{tabular}

Yaprak Dokusu: Çizelge 4'de, yaprak dokusu bulgularımıza uygulanan analiz sonuçları incelenen çim bitkileri arasında önemli farklılıkların oluştuğunu göstermektedir. Yaprak dokusu bakımından en yüksek değerlere sahip olan bir başka ifade ile yaprak ayası en geniş türler, kamışsı yumak çeşitlerinde $3.6 \mathrm{~mm} \quad(\mathrm{kaba})$ olarak belirlenmiştir. En düşük değerler de $1.3 \mathrm{~mm}$ (ince) ile kırmızı yumak ve $1.7 \mathrm{~mm}$ (ince) ile çayır salkımotu türlerinde saptanmıştır. İngiliz çimi çeşitleri ise benzer değerde, ortalama 2.1 $\mathrm{mm}$ ile "orta" doku içermişlerdir. Yaprak dokusuna ilişkin bulgularımız kırmızı yumak çeşitleri arasında Pernille'nin en ince dokuya sahip olduğunu ortaya koymakta, ancak bu kısımdaki farklılıklar istatistik açıdan önem taşımamaktadır. Bazı araştırıcılar yumakların özellikle yaprak ayalarının katlanarak ince doku içerdiklerini açıklamakta (Hubbard 1992) ve sonuçlarımızı doğrulamaktadırlar. Çeşitler arasında önemli bir farklılığın saptanmamış olması, bölge koşullarında tüm çeşitlerin benzer performans gösterdiklerini ortaya koymakta ve bu genotiplerin yörenin iklim koşullarında, yaprak dokusu açısından bir modifikasyon göstermediklerini doğrulamaktadır. Benzer durum kamışsı yumak açısından da belirlenmiş ve kamışsı yumağın en kaba dokulu çimler arasında yer aldığını belirten, Demiroğlu ve Soya (2000)'nın sonuçlarıyla uyumlu bulunmuştur. Ancak Finelawn ve Apache çeşitlerinin nispeten yakın tarihlerde ıslah edildiği bilinen Eldorado çeşidinden daha kaba dokulu oldukları da izlenmiştir. İngiliz çimi çeşitleri arasında, Ovation ve Delaware çeşitlerinin Numan çeşidinden önemli düzeyde daha kaba dokulu oldukları izlenmekte bu da Numan çeşidinin daha ince dokulu çim alanların oluşturulmasına elverişli bulunduğunu ortaya koymaktadır. Soğuk iklimlerde dünyanın en iyi çimlerinden kabul edilen Çayır salkımotu çeşitleri de, daha önceki çalışmalarda ortaya konulan sonuçları doğrulamış (Hubbard 1992) ve ince dokularıyla dikkati çekmişlerdir. Bu özellikleri açısından Enprima ve Conni, Geronimo'dan daha başarılı görülmüştür.

Yenilenme Gücü: Araştırmada ele alınan çim buğdaygillerinin yenilenme gücü açısından kamışsı yumak çeşitlerinin 2.0 puan ile en yüksek değere ulaştığı, İngiliz çimi çeşitlerinin 
ise ortama 3.0 puanla bu çimi izlediği saptanmıştır (Çizelge 4). Yenilenme gücü açısından, kırmızı yumak 4.0 puan ve Çayır salkımotu 5.0 puan ile oldukça başarısız sonuçlar vermişlerdir. Araştırma yerinin Akdeniz iklim koşullarında, sıcak ve kurak yaz ayları sonunda ve 12 aylık dönem tamamlandığında saptanan yenilenme gücü değerleri, sıcak ve kurağa dayanıklılığı ile ünlü kamışsı yumak çeşitlerinin tümünün çok başarılı olduğunu ve tam bir yenilenme gücü gösterdiklerini ortaya koymaktadır. Bu açıdan İngiliz çimi çeşitleri de nispeten başarılı olmuş ve parsellerini kabul edilebilir bir düzeyde devam ettirdikleri gözlenmiştir (Çizelge 4). Buna karşılık, özellikle kırmızı yumak ve Çayır salkımotu çeşitlerine ait parsellerin adeta boşaldığı izlenmiş, bu durum da çok düşük puanların ortaya çıkmasına neden olmuştur. Yenileme gücüne ilişkin bulgularımız, kamışsı yumak ve İngiliz çiminin Akdeniz iklim koşullarında başarılı olabileceğini belirten Avcıoğlu, (1997)'nın bulgularını doğrulamaktadır. Bu sonuçlar özellikle Ege bölgesi koşullarında çayır salkımotu ve kırmızı yumak çeşitlerinin kullanılmaması gerektiğini ve soğuk iklimlere adapte olan bu çeşitlerin, bölgede karasal iklimin etkisi olan yerlerde kullanılmasının zorunlu olduğu görüşünü güçlendirmektedir (Soya, H., Avcıoğlu ,R., Saygılı, H., Geren, H., Kır, B., Çetinkaya, N., Türküsay, H., Gümüş, M., 2003).
Renk: Çizelge 5'de denememizde yer alan yeşil alan çim bitkilerinin 4 mevsim boyunca ortaya koydukları renk değerleri puan olarak özetlenmiştir.

Kış: Çizelge 5'de yer alan kış mevsimi renk değerleri incelendiğinde, en iyi yeşil renk ortalamasının 7.0 puan ile kırmızı yumak türüne ait çeşitlerde, en olumsuz renk ortalamasının ise 5.3 puan ile İngiliz çimi türüne ait çeşitlerde saptandığı izlenmektedir. Kamışsı yumak ve çayır salkımotu 6.0 ve 6.8'lik ortalama ile bu iki türün arasında yer almışlardır.

İlkbahar: İlkbahar renk puanları incelendiğinde en yüksek renk puanı yine kırmızı yumak türüne ait çeşitlerde (ortalama 8.8), en düşük puan ise çayır salkımotu türlerine ait çeşitlerde ortalama 6.8 olarak belirlenmiştir. İngiliz çimi ve kamışsı yumak türleri ortalama 7.3 ve 7.8 puan ile bu iki cinse ait çeşitler arasında yer almıştır.

Yaz: Çizelge 5'in yaz dönemi renk değerlerine ilişkin verilerinden de izlenebileceği gibi, en yüksek ortalama puan 5.8 ile kamışsı yumak çeşitlerinde en düşük puan ise 1.3 ile kırmızı yumak çeşitlerinde saptanmıştır. Çayır salkımotu çeşitlerinden Enprima'da da ortalama 1.3 renk puanı belirlenmiştir. Bu dönemde İngiliz çimi çeşitleri ise ortalama 3.3 puan ile ikinci sırada yer almışlardır.

Çizelge 5. Kamışsı yumak (Festuca arundinaceae), kırmızı yumak (Festuca rubra), ìngiliz çimi (Lolium perenne) ve çayır salkımotu (Poa pratensis) çeşitlerinin yaprak rengi (1-9 Puan)

Table 5. Leaf color (1-9 points) of tall fescue (Festuca arundinacea), red fescue (Festuca rubra), the british grass (Lolium perenne) and bluegrass (Poa pratensis) types

\begin{tabular}{|c|c|c|c|c|c|c|}
\hline \multirow{2}{*}{ Çim Buğdaygilleri } & \multirow{2}{*}{ Çeşitler } & \multicolumn{4}{|c|}{ Yaprak Rengi } & \multirow{2}{*}{ Ortalama } \\
\hline & & Kış & İlkbahar & Yaz & Sonbahar & \\
\hline \multirow{3}{*}{$\begin{array}{l}\text { Kamışsı Yumak } \\
\text { (Festuca arundinaceae) }\end{array}$} & Eldorado & $6.0 \mathrm{~b}$ & $7.8 \mathrm{~b}$ & $5.8 a$ & $8.8 a$ & 7.1 \\
\hline & Finelawn & $6.0 \mathrm{~b}$ & $7.8 \mathrm{~b}$ & $5.8 a$ & $8.8 a$ & 7.1 \\
\hline & Apache & $6.0 \mathrm{~b}$ & $7.8 \mathrm{~b}$ & $5.8 a$ & $8.8 a$ & 7.1 \\
\hline Ortalama & & 6.0 & 7.8 & 5.8 & 8.8 & 7.1 \\
\hline \multirow{3}{*}{$\begin{array}{l}\text { Kırmızı Yumak } \\
\text { (Festuca rubra) }\end{array}$} & Engina & $7.0 a$ & $8.8 a$ & $1.3 \mathrm{c}$ & $5.8 \mathrm{c}$ & 5.7 \\
\hline & Franklin & $7.0 a$ & $8.8 a$ & $1.3 c$ & $5.8 \mathrm{c}$ & 5.7 \\
\hline & Pernille & $7.0 \mathrm{a}$ & $8.8 a$ & $1.3 \mathrm{c}$ & $5.8 \mathrm{c}$ & 5.7 \\
\hline Ortalama & & 7.0 & 8.8 & 1.3 & 5.8 & 5.7 \\
\hline \multirow{3}{*}{$\begin{array}{l}\text { İngiliz Çimi } \\
\text { (Lolium perenne) }\end{array}$} & Numan & $5.3 \mathrm{c}$ & $7.3 \mathrm{bc}$ & $3.3 b$ & $7.3 \mathrm{~b}$ & 5.8 \\
\hline & Ovation & $5.3 \mathrm{c}$ & $7.3 \mathrm{bc}$ & $3.3 b$ & $7.3 b$ & 5.8 \\
\hline & Delaware & $5.3 \mathrm{c}$ & $7.3 \mathrm{bc}$ & $3.3 b$ & $7.3 b$ & 5.8 \\
\hline Ortalama & & 5.3 & 7.3 & 3.3 & 7.3 & 5.8 \\
\hline \multirow{3}{*}{$\begin{array}{l}\text { Çayır Salkımotu } \\
\text { (Poa pratensis) }\end{array}$} & Enprima & $6.8 a$ & $6.8 \mathrm{c}$ & $1.3 \mathrm{c}$ & $6.8 \mathrm{~b}$ & 5.4 \\
\hline & Geronimo & $6.8 a$ & $6.8 \mathrm{c}$ & $1.5 \mathrm{c}$ & $6.8 \mathrm{~b}$ & 5.4 \\
\hline & Conni & $6.8 a$ & $6.8 \mathrm{c}$ & $1.8 \mathrm{c}$ & $6.8 \mathrm{~b}$ & 5.6 \\
\hline Ortalama & ------ & 6.8 & 6.8 & 1.5 & 6.8 & 5.5 \\
\hline Genel Ortalama & ----- & 6.3 & 7.7 & 3.0 & 7.1 & 6.0 \\
\hline LSD (\%5) & ------ & 0.457 & 0.626 & 0.709 & 0.719 & 0.378 \\
\hline
\end{tabular}


Sonbahar: Sonbaharda tüm cinslere ait renk puanları yükselmiş ve kamışsı yumak çeşitlerinde 8.8, İngiliz çimi çeşitlerinde 7.3, çayır salkımotu çeşitlerinde 6.8 ve kırmızı yumak çeşitlerinde 5.8'lik ortalama renk değerleri saptanmıştır.

Dört mevsimin ortalaması olarak renk değerleri ele alındığında, kamışsı yumak çeşitlerinin ortalama 7.1 puan ile yine ilk sırayı aldığı, onları İngiliz çimi çeşitlerinin izlediği görülmektedir (Çizelge 5). Bu bölümde, İngiliz çimi 5.8 ortalama ile 2 . sırada yer almış, kırmızı yumak çeşitleri 5.7 ortalama ile onları izlemiştir. Çayır salkımotu çeşitleri ise ortalama 5.5 renk puanı ile son sırada yer almışlardır. Araştırmada ele alınan çim cins ve çeşitlerinin dört mevsimde ve genel ortalamada ortaya koydukları renk performansları, kamışsı yumak çeşitlerinin aralarında fark olmaksızın en iyi sonucu verdiklerini açıkça ortaya koymaktadır. Kış, İlkbahar ve Sonbahar dönemlerinde oldukça yüksek puanlar alan İngiliz çimi çeşitlerinin, yaz döneminde renk puanlarının düştüğü anlaşılmakta ve yaz stresi dışında, bu çeşitlerin de aralarında fark olmaksızın doyurucu bir renk özelliğini sürdürebildikleri sonucuna varılmaktadır. Renk özellikleri açısından çayır salkımotu ve kırmızı yumak çeşitlerinin oldukça sınırlı sonuçlar ortaya koyması beklenene uymaktadır. Özellikle çayır salkımotu soğuk karasal iklimlerin ideal çim bitkisi olduğundan araştırmamızın Akdeniz iklim koşullarında olduğunda başarılı olamamıştır ve düşük renk puanları ortaya koymuştur (Shanqiang ve Chiwon 1996). Benzer durum kırmızı yumak içinde geçerlidir (Anonim 2008).

Kardeş Sayısı: Çizelge 6'nın kamışsı yumak, kırmızı yumak, çayır salkımotu ve İngiliz çimi çeşitlerinin kardeş sayısı özelliklerini ortaya koyan bölümü incelendiğinde çayır salkımotu çeşitleri dışındaki türler ve çeşitler arasında önemli bir fark olmadığı (kırmızı yumak ve kamışsı yumak ortalama 4.8 puan, İngiliz çimi ortalama 4.3 puan) görülmektedir. Buna karşılık, çayır salkımotu türüne ait çeşitlerin, ortalama 2.8 puan ile diğer 3 türe ait çeşitlerin çok gerisinde kaldıkları izlenmiştir.

Araştırmamızın bu bölümünde kardeş sayısına ilişkin bulgularımız, diğer özellikler açısından elde ettiğimiz verilere paralel olarak, kamışsı yumak ve İngiliz çimi çeşitlerinin iyi bir

Çizelge 6. Kamışsı yumak (Festuca arundinaceae), kırmızı yumak (Festuca rubra), İngiliz çimi (Loliumsperenne) ve çayır salkımotu (Poa pratensis) çeşitlerinin kardeş sayısı (1-5 Puan) seyrekleşme derecesi (1-9 Puan) ve yabancı bitki oranı (1-5 Puan)

Table 6. Number of tiller (1-5 points) thinning grade (1-9 points) and foreign plants percentage (1-5 points) of tall fescue (Festuca arundinacea), red fescue (Festuca rubra), the British grass (Lolium perenne) and bluegrass (Poa pratensis) types

\begin{tabular}{llccc}
\hline Çim Buğdaygilleri & Çeşitler & Kardeş Sayısı & $\begin{array}{c}\text { Seyrekleşme } \\
\text { Derecesi }\end{array}$ & $\begin{array}{c}\text { Yabancı Bitki } \\
\text { Oranı }\end{array}$ \\
\hline Kamışsı Yumak & Eldorado & $4.8 \mathrm{a}$ & $7.8 \mathrm{a}$ & $4.8 \mathrm{a}$ \\
(Festuca arundinaceae) & Finelawn & $4.8 \mathrm{a}$ & $7.8 \mathrm{a}$ & $4.8 \mathrm{a}$ \\
& Apache & $4.8 \mathrm{a}$ & $7.8 \mathrm{a}$ & $4.8 \mathrm{a}$ \\
Ortalama & & 4.8 & 7.8 & 4.8 \\
\hline Kırmızı Yumak & Engina & $4.8 \mathrm{a}$ & $1.3 \mathrm{~d}$ & $2.8 \mathrm{~b}$ \\
(Festuca rubra) & Franklin & $4.8 \mathrm{a}$ & $1.3 \mathrm{~d}$ & $2.8 \mathrm{~b}$ \\
& Pernille & $4.8 \mathrm{a}$ & $1.3 \mathrm{~d}$ & $2.8 \mathrm{~b}$ \\
Ortalama & 4.8 & 1.3 & 2.8 \\
\hline \multirow{2}{*}{ Ingiliz Çimi } & Numan & $4.3 \mathrm{a}$ & $4.8 \mathrm{~b}$ & $4.3 \mathrm{a}$ \\
(Lolium perenne) & Ovation & $4.3 \mathrm{a}$ & $4.8 \mathrm{~b}$ & $4.3 \mathrm{a}$ \\
Ortalama & Delaware & $4.3 \mathrm{a}$ & $4.8 \mathrm{~b}$ & $4.3 \mathrm{a}$ \\
\hline \multirow{2}{*}{ Çayır Salkımotu } & 4.3 & 4.8 & 4.3 \\
(Poa pratensis) & & $2.8 \mathrm{~b}$ & $2.3 \mathrm{c}$ & $1.3 \mathrm{c}$ \\
Ortalama & Enprima & $2.8 \mathrm{~b}$ & $2.3 \mathrm{c}$ & $1.3 \mathrm{c}$ \\
\hline Genel Ortalama & Geronimo & $2.8 \mathrm{~b}$ & $2.3 \mathrm{c}$ & $1.3 \mathrm{c}$ \\
LSD (\%5) & Conni & 2.8 & 2.3 & 1.3 \\
\hline
\end{tabular}


kardeşlenme gösterdiğini ortaya koymuştur. Pek çok araştırıcı da sonuçlarımızı doğrulayan veriler açıklamaktadırlar (Bilgili ve Açıkgöz 2005). Ancak, pek çok özellik açısından gerilerde kalan kırmızı yumak çeşitlerinin de çok sayıda kardeş oluşturduğu izlenmekte, bunun da stres koşullarına tepki olarak ortaya çıktığı izlenimi elde edilmektedir (Salisbury ve Ross 1992). Bu bölümde, sıcak iklimlere adapte olamadığı ve soğuk karasal iklimlerin en değerli çimlerinden biri olduğu bilinen çayır salkımotu çeşitlerinin, deneme koşullarımızda gelişemeyip iyi kardeşlenemediğini gösteren değerler beklenene uymaktadır (Hubbard 1992).

Seyrekleşme Derecesi: Araştırmamızın tür ve çeşitleri ortalama seyrekleşme derecesi açısından ele alındığında, belirgin farklııklar saptanmakta, kamışsı yumak (7.8) ve İngiliz çim (4.8) çeşitleri oldukça yüksek ortalamalar sergilemektedir. Buna karşılık kırmızı yumak çeşitlerinde (1.3) aşırı düzeyde seyrelme izlenmekte, aynı olumsuzluk çayır salkımotu çeşitlerinde (2.3) de gözlenmektedir. $\mathrm{Bu}$ sonuçlar, benzer çalışmaları yürüten araştıııcıların sonuçlarını doğrulamakta ve araştırmanın Akdeniz iklim koşullarında, kamışsı yumak ve İngiliz çimi çeşitlerinin aşırı bir seyrelme göstermeden adapte olabildiklerini çayır salkımotu ve özellikle kırmızı yumak çeşitlerinin ise daha ilk vejetasyon döneminde hızla seyreldiklerini göstermektedir (Avcıoğlu 1997).

Yabancı Bitki Oranı: Bu bölümde seyrekleşmeye paralel olarak, ortalama yabancı bitki puanı açısından da yine kamışsı yumak (4.8) ve İngiliz çimi (4.3) çeşitlerinin çok az yabancı bitki içerdikleri saptanmakta, buna karşılık iyice seyrelen kırmızı yumak (2.8), çayır salkımotu (1.3) çeşitlerinin, tam bir yabancı bitki istilasıyla çok düşük yabancı bitki puanları aldıkları izlenmektedir.

$\mathrm{Bu}$ bölümde incelenen her 3 karakter açısından her tür içindeki çeşitler arasında önemli farklılıklar oluşmadığı istatistik analiz sonuçlarıyla da doğrulanmaktadır.

Genel Görünüm: Çalışmanın 4 mevsime ilişkin genel görünüm değerleri, topluca ve ortalama değerler olarak incelendiğinde, kamışsı yumak çeşitlerinin ortalama puanlar açısından (Eldorado 7.2, Finelawn 7.3, Apache 7.2) oldukça dengeli bir dağılış gösterdiği ve yüksek ortalamalar içerdiği anlaşıımaktadır. Bu açıdan

Çizelge 7. Kamışsı yumak (Festuca arundinaceae), kırmızı yumak (Festuca rubra), ingiliz çimi (Lolium perenne) ve çayır salkımotu (Poa pratensis) çeşitlerinin genel görünümü (1-9 Puan)

Table 7. Overview (1-9 points) of tall fescue (Festuca arundinacea), red fescue (Festuca rubra), the british grass (Lolium perenne) and bluegrass (Poa pratensis) types

\begin{tabular}{lllllll}
\hline \multicolumn{1}{c}{ Çim Buğdaygilleri } & Çeşitler & Kış & İlkbahar & Yaz & Sonbahar & Ortalama \\
\hline \multirow{2}{*}{ Kamışsı Yumak } & Eldorado & $7.8 \mathrm{a}$ & $7.3 \mathrm{a}$ & $6.5 \mathrm{a}$ & $7.2 \mathrm{a}$ & 7.2 \\
(Festuca arundinaceae) & Finelawn & $7.8 \mathrm{a}$ & $7.3 \mathrm{a}$ & $6.8 \mathrm{a}$ & $7.1 \mathrm{~b}$ & 7.3 \\
& Apache & $7.8 \mathrm{a}$ & $7.3 \mathrm{a}$ & $6.8 \mathrm{a}$ & $7.0 \mathrm{~b}$ & 7.2 \\
Ortalama & & 7.8 & 7.3 & 6.7 & 7.1 & 7.2 \\
\hline \multirow{2}{*}{ Kırmızı Yumak } & Engina & $4.8 \mathrm{c}$ & $6.8 \mathrm{a}$ & $1.3 \mathrm{~d}$ & $1.5 \mathrm{~h}$ & 3.6 \\
(Festuca rubra) & Franklin & $4.8 \mathrm{c}$ & $6.8 \mathrm{a}$ & $1.3 \mathrm{~d}$ & $1.4 \mathrm{~h}$ & 3.6 \\
& Pernille & $4.8 \mathrm{c}$ & $6.8 \mathrm{a}$ & $1.3 \mathrm{~d}$ & $1.5 \mathrm{~h}$ & 3.6 \\
Ortalama & & 4.8 & 6.8 & 1.3 & 1.5 & 3.6 \\
\hline \multirow{2}{*}{ Ingiliz Çimi } & Numan & $7.8 \mathrm{a}$ & $6.8 \mathrm{a}$ & $4.5 \mathrm{~b}$ & $5.5 \mathrm{~d}$ & 6.1 \\
(Lolium perenne) & Ovation & $7.8 \mathrm{a}$ & $6.8 \mathrm{a}$ & $4.8 \mathrm{~b}$ & $5.4 \mathrm{e}$ & 6.2 \\
& Delaware & $7.8 \mathrm{a}$ & $6.8 \mathrm{a}$ & $4.5 \mathrm{~b}$ & $5.6 \mathrm{c}$ & 6.2 \\
Ortalama & & 7.8 & 6.8 & 4.6 & 5.5 & 6.2 \\
\hline \multirow{2}{*}{ Çayır Salkımotu } & Enprima & $5.8 \mathrm{~b}$ & $4.3 \mathrm{~b}$ & $2.3 \mathrm{c}$ & $3.4 \mathrm{f}$ & 4.0 \\
(Poa pratensis) & Geronimo & $5.8 \mathrm{~b}$ & $4.3 \mathrm{~b}$ & $2.3 \mathrm{c}$ & $3.2 \mathrm{~g}$ & 3.9 \\
& Conni & $5.8 \mathrm{~b}$ & $4.3 \mathrm{~b}$ & $2.5 \mathrm{c}$ & $3.3 \mathrm{~g}$ & 4.0 \\
Ortalama & ------ & 5.8 & 4.3 & 2.4 & 3.3 & 4.0 \\
\hline Genel Ortalama & ----- & 6.6 & 6.3 & 5.3 & 4.4 & 5.3 \\
LSD (\%5) & ---- & 0.701 & 0.655 & 0.695 & 0.092 & \\
\hline
\end{tabular}


İngiliz çimi çeşitleri de (Numan 6.1, Ovation 6.2, Delaware 6.2) oldukça başarılı sonuçlar vermiş ve kamışsı yumaktan sonra ikinci sırayı almışlardır. Buna karşılık, kırmızı yumak çeşitleri Kış ve İlkbahar döneminde kabul edilebilir sınırlarda olan genel görünüm puanlarını çok düşürmüş ve tüm çeşitler (Engina 3.6, Franklin 3.6, Pernille 3.6) Yaz ve Sonbahar dönemindeki çok düşük genel görünüm puanlarıyla, çok olumsuz bir sonuç ortaya koymuşlardır. Benzer durum çayır salkımotu çeşitlerinde de (Enprima 4.0, Geronimo 3.9, Conni 4.0) izlenmiş ve özellikle Yaz ve Sonbahar dönemlerindeki düşüşler nedeni ile çok sınırlı genel görünüm puanlarına sahip olmuşlardır (Çizelge 7). Çalışmamızın 4 mevsimi içeren genel görünüm puanlarına ilişkin verileri, bölgenin Kış koşulları kadar yaz ve sonbahar koşullarına da çok iyi adapte olabilen kamışsı yumak çeşitlerinin en başarıı çim buğdaygilleri olduğunu açıkça ortaya koymaktadır. Bu sonuçlar, kamışsı yumağın sıcak ve kurağa dayanıklıığını öne süren pek çok araştırııının bulgularıyla doğrulanmaktadır (Avcıoğlu 1997; Hubbard 1992). Dünya'da da yaygın olarak kullanılan ve değişik iklim koşullarına uyumu ile bilinen İngiliz çimi çeşitleri de 4 ayrı mevsimde yöreye adapte olabildiklerini, genel görünüm puanlarıyla ortaya koyabilmişlerdir. Bu nedenle, İngiliz çimi çeşitlerinin de iyi bakım koşullarında, kamışsı yumak ile birlikte başarı ile kullanılabileceği izlenimi edinilmiştir (Salman ve Avcıoğlu 2008). Genel görünüm puanları açısından, özellikle Yaz ve Sonbahar mevsimlerindeki sıcak koşulların etkisiyle, düşük puanlara sahip olan tüm kırmızı yumak ve çayır salkımotu çeşitlerinin ise araştırma koşullarında genel görünüm olarak çok olumsuz sonuçlar verdikleri ve yöre koşullarına adapte olamayacakları kesin kanaatine varılabilmektedir. Bölgede yürütülen pek çok araştırma sonucu da bu kanaati doğrulamaktadır (Gül ve Avcıoğlu 1997).

\section{Sonuç}

Elde ettiğimiz bulgulara göre çıkış hızı bakımından İngiliz çimi en hızlı çıkışı göstermiştir. Yine bununla beraber kaplama hızı açısından İngiliz çiminin tüm çeşitleri en iyi kaplama hızını göstermişlerdir. Kışa dayanıklııı bakımından ise, hemen hemen tüm türlere ait çeşitler serin iklim bitkisi olmalarının da etkisiyle, çok başarılı sonuçlar sergilemişlerdir. Kamışsı yumak çeşitleri kaplama derecesi açısından diğer türlere ait çeşitleri geride bırakarak en başarılı sonuçları vermişlerdir. Yine yaprak dokusu açısından da kamışsı yumak çeşitlerinin kaba bir dokuya sahip oldukları, kırmızı yumak çeşitlerinin ise en ince dokuya sahip oldukları saptanmıştır. Kamışsı yumak çeşitlerinin yenilenme gücü açısından da diğer çeşitlere kıyasla çok daha başarıı sonuçlar vermiş oldukları gözlemlenmiştir. Dört mevsim ortalaması olarak renk özelliği açısından kamışsı yumak çeşitleri yine ilk sırada yer almışlardır. Kardeş sayısı bakımından gözlemlenen bulgulara baktığımızda da, kamışsı yumak, kırmızı yumak ve İngiliz çimi türlerine ait çeşitler, çayır salkımotu çeşitlerine oranla daha başarıı olmuşlardır. Seyrekleşme derecesi açısından en az seyrekleşme kamışsı yumak çeşitlerinde görülmüştür. Bunun aksine kırmızı yumak çeşitleri ise bölgenin yaz iklim koşullarına uyum sağlayamayıp hızla seyrelmişlerdir. Yabancı bitki oranı bakımından ise, yine kamışsı yumak çeşitleri diğer türlere ait çeşitlerden çok daha başarılı sonuçlar ortaya koymuşlardır. Genel görünüm özellikleri açısından, tüm mevsimler ortalamasına bakarak, yine kamışsı yumak çeşitlerinin en başarılı olduğu, onu İngiliz çimi çeşitlerinin takip ettiği çayır salkımotu ile kırmızı yumak çeşitlerinin araştırma yeri koşullarında en olumsuz sonuçları sergilediği de açıkça gözlenmiştir. Ayrıca Ege bölgesi İzmir Bornova yöresinde yürüttüğümüz çalışmanın toplu sonuçları, Akdeniz ikliminin hüküm sürdüğü yörelerde önerilebilecek çim bitkilerinin kamışsı yumak ve İngiliz çimi olduğu kanaatini ortaya koymuştur. İyi bakım koşullarında, İngiliz çiminin yaz mevsimini çok zarar görmeden atlatabileceği saptanmıştır. Kamışsı yumağın Akdeniz iklim koşullarında yararlanılacak en dayanıklı yeşil alan bitkisi olduğu da kanıtlanmıştır.

\section{Kaynaklar}

Açıkgöz E., 1994. Çim Alanlar Yapım ve Bakım Tekniği, Uludağ Üniversitesi Ziraat Fakültesi, Bursa

Anonym 2008. Characterization of phytosiderophore secretion under Fe deficiency stres in Festuca rubra, Plant and Soil 256: 131-137, 2003, Kluwer Academic Publishers 2003

Arslan M., ve Çakmakçı S., 2004. Farklı çim tür ve çeşitlerinin Antalya ili sahil koşullarında, adaptasyon yeteneklerinin ve performanslarının belirlenmesi, Akdeniz Üniversitesi Ziraat Fakültesi Dergisi, 17(1): $31-42$ 
Avcıoğlu R., 1992. Yeşil Alan ve Erozyon Kontrol Buğdaygilleri, Ders Notları, Ege Üniversitesi Ziraat Fakültesi, Bornova- İzmir

Avcıoğlu R., 1997. Çim tekniği, yeşil alanların ekimi, dikimi ve bakımı, Ege Üniversitesi Ziraat Fakültesi Tarla Bitkileri Anabilim Dalı, 271s. Bornova-İzmir

Bilgili U. ve Açıkgöz E., 2005. Year round nitrogen fertilization effects on growth and quality of sports turf mixtures, journal of plant nutrition, 28(2): 299-307

Cockerham S. T. V. A., Gıbeault J. Van Dam and Leonard M. K., 1989. Tolerance of cool season turf grasses to sports traffic, cali turf grass culture, University of California- USA, 39: 12-14

Demiroğlu G. ve Soya H., 2000. Bazı Serin İklim Buğdaygillerinin Akdeniz İklim Kuşağındaki Agronomik Özellikleri Üzerinde Araştırmalar Yüksek Lisans Tezi

Gül A. ve Avcıoğlu R., 1997. Bazı Yeşil Alan Buğdaygillerinin Ege Bölgesi Sahil Kuşağında Kullanma Uygunluğu ve Değişik Çim Yatağı Üzerindeki Performansının Araştırılması, Ege Üniversitesi Fen Bilimleri Enstitüsü Tarla Bitkileri Anabilim Dalı, İzmir. (Basılmamış Doktora Tezi), 130s

Hubbard C.E., 1992. Grasses Penguin Books, London, England, $450 \mathrm{pp}$

Kacar B., 1986. Bitki Besleme, Ankara Üniversitesi Ziraat Fakültesi Yayınları No: 637, Ankara, $318 \mathrm{~s}$

Kovancı İ., 1990. Bitki Besleme ve Toprak Verimliliği, Ders Notları, Ege Üniversitesi Ziraat Fakültesi Teksir No: 107-3, Bornova-İzmir, 286s
Orçun E., 1979. Özel Bahçe Mimarisi (Çim Sahaları Tesis ve Bakım Tekniği), Ege Üniversitesi Ziraat Fakültesi, Yayın No: 152, Bornovaİzmir

Salisbury F.B. and Ross C.W., 1992 Plant Physiology. Wadsorth Pub. Com., Inc., Belmont, California-USA

Salman A. ve Avcıoğlu R., 2008. Farklı Gübre Dozlarının Bazı Serin ve Sıcak İklim Çimlerinin Yeşil Alan Performanslarına Etkisi, Ege Üniversitesi Fen Bilimleri Enstitüsü Tarla Bitkileri Anabilim Dalı, İzmir. (Basılmamış Doktora Tezi), 170s

Shanqiang K. and Chiwon W. L., 1996. Plant regeneration in Kentucky bluegrass (Poa pratensis L.) via coleoptile tissue cultures Department of Plant Sciences, North Dakota State University, Fargo, ND 58105, USA September 1996, Volume 15, Issue 12, pp 882-887

Soya H., Avcıoğlu R., Saygılı H., Geren H., Kır B., Çetinkaya N., Türküsay H., Gümüş M., 2003. Türkiye'de Çim, Çayır-Mer'a ve Yem bitkileri Tohumluğu Üzerinde Araştırmalar, TÜBITAK Proje No:TARP-2236

Uçucu R., 1993. Tarla Tarımı Mekanizasyonu, Ders Notları (basılmamış), Ege Üniversitesi Ziraat Fak. Tarım Makinaları Bölümü, Bornova-İzmir

Yazgan M.E., Ekiz H., Karadeniz N. ve Kendir H., 1992. Ankara Koşullarında Yeşil Saha Tesisinde Kullanılabilecek Önemli Çim Türlerinin Belirlenmesinde Bazı Morfolojik ve Fenolojik Karakterler Üzerinde Bir Araştırma, Ankara Üniversitesi Ziraat Fakültesi Yayınları, 1277, Ankara, 38s 